\title{
Estudo de caso: Análise Ambiental da Implantação de Abatedouro no Município de São Gonçalo do Amarante/RN
}

\author{
Case study: Environmental Analysis of the Slaughterhouse Implantation in the Municipality \\ of São Gonçalo do Amarante / RN
}
CARVALHO SEGUNDO', E. L.; GALVÃO², S. P. M.; LIMA, P. H. G.; BORGES FILHO ${ }^{4}$, R. D. espedito_19@hotmail.com

\begin{abstract}
Resumo
Este trabalho relata o estudo de caso para análise das alternativas locacionais para futura implantação de um empreendimento de suporte a agroindústria local denominado de Abatedouro Público, com vista a uma breve análise dos impactos ambientais e infraestrutura que necessitam para a viabilidade de tal atividade. Foram analisadas 3 (três) áreas no município, o qual estas estão inseridas em área de dunas, planície fluvial e tabuleiros. Através das observações in loco e fotointerpretação do mapeamento em software SIG - Sistema de Informação Geográfica, elaborado da integração das características ambientais das áreas de interesse (relevo, vegetação, solos e hidrografia), foi possível determinar a melhor área para implantação de tal empreendimento.
\end{abstract}

Palavras-chaves: Viabilidade ambiental, impacto ambiental, abatedouro público.

\begin{abstract}
This paper reports the case study for the analysis of locational alternatives for future implementation of a local agroindustry support project called Public Abattoir, with a view to a brief analysis of the environmental impacts and infrastructure that they need for the feasibility of such activity. Three (3) areas were analyzed in the municipality, which are inserted in an area of dunes, fluvial plain and trays. Through the in situ observations and photointerpretation of the mapping in GIS software Geographic Information System, elaborated of the integration of the environmental characteristics of the areas of interest (relief, vegetation, soils and hydrography), it was possible to determine the best area for implementation of such an enterprise.
\end{abstract}

Keywords: Environmental viability, environmental impact, $\quad$ public slaughterho

\section{INTRODUÇÃO}

A Biogeografia tem como a sua principal tarefa, explicar a distribuição dos seres vivos na Terra, com diferentes escalas de tempo e espaço. Dessa forma, a Biogeografia estuda os campos da Geografia Física e Humana. Os estudos se caracterizam em buscar uma melhor compreensão da paisagem com uma análise integrada dos elementos, partindo da distribuição da vegetação na

\footnotetext{
${ }^{1}$ Espedito Lima de Carvalho Segundo, Biólogo, Secretaria Municipal de Meio Ambiente e Urbanismo, São Gonçalo do Amarante-RN, Brasil.

${ }^{2}$ Sílvio Petronilo de Medeiros Galvão, Tecnólogo Ambiental, Secretaria Municipal de Meio Ambiente e Urbanismo, São Gonçalo do Amarante-RN, Brasil.

${ }^{3}$ Pedro Henrique Godeiro de Lima, Geógrafo, Secretaria Municipal de Meio Ambienta e Urbanismo, São Gonçalo do Amarante-RN, Brasil.

${ }^{4}$ Ridon Dantas Borges Filho, graduando em Engenharia Ambiental e Sanitária, Secretaria Municipal de Meio Ambienta e Urbanismo, São Gonçalo do Amarante-RN, Brasil.
} 
superfície terrestre e a influência do homem. Segundo Brown \& Lomolino (2006), a definição formulada sobre a Biogeografia:

"A Biogeografia é um campo de conhecimento interdisciplinar da Geografia e das Ciências Biológicas que pesquisa o modo como os seres vivos se distribuem no tempo e no espaço". "É o estudo da biodiversidade espacializada".

Para Santos \& Carvalho (2012), "cabe ao biogeógrafo, através do uso de métodos e técnicas específicas compreender o sprocessos e leis naturais que determinam a dinâmica das paisagens, como também o uso racional do espaço e dos recursos naturais dessa mesma paisagem." A Biogeografia tem sido um dos ramos da geografia que tem contribuído bastante no entendimento dos atuais processos de degradação da natureza (Santos \& Carvalho, 2012).

Dessa forma, desde o inicio do mundo globalizado a figura do homem altera o espaço geográfico com suas relações voltadas ao meio ambiente. Porém, as práticas que seriam para a existência humana passam a ter outras relações no território. Com o advento da modernização e da tecnologia, cada vez mais o homem capitaneado pelo sistema de acumulação, busca sem precedentes exploração dos recursos naturais, causando impactos.

O crescimento populacional faz aumentar a demanda por produtos e serviços, que por sua vez, potencializaram a geração de resíduos sólidos e efluentes líquidos. Nessa perspectiva, os abatedouros são geradores de efluentes e de resíduos de grande potencial poluidor. O problemas ambientais gerados por tal atividade estão relacionados com os seus despejos ou resíduos oriundos de diversas etapas do processamento industrial, o qual os principais impactos negativos são: geração de efluentes líquidos que podem provocar contaminação dos solos e das águas superficiais e subterrâneas, além do odor da decomposição do material orgânico.

O conceito de impacto ambiental, abrange várias áreas, mas que propõem unicamente os traumas referentes a natureza, através de um conjunto de ações antrópicas causando danos e alterações ao meio ambiente.

Considerando a importância de conhecer e buscar medidas para um desenvolvimento sustentável, a proposta do presente estudo é à análise das alternativas locacionais para futura implantação de um empreendimento de suporte a agroindústria local denominado de Abatedouro Público, com vista a uma breve análise dos impactos ambientais e infraestrutura que necessitam para a viabilidade de tal atividade, usando as ferramentas de software SIG - Sistema de Informação Geográfica. Com isso, para alcançar tal finalidade, foi preciso analisar os principais aspectos relacionados ao uso e ocupação do solo da área do empreendimento; caracterizar o quadro natural 
da área de estudo quanto aos elementos: geológicos, geomorfológicos, e biótico; identificar áreas de restrição ambiental e/ou ambientalmente sensíveis, dentro da área de influência direta do empreendimento e identificar e propor o espaço geográfico mais adequada para implantação do empreendimento considerando a legislação vigente. Sobre o uso de ferramentas de SIG na Biogeografia:

"Os estudos da espacialização da biodiversidade têm se tornado fundamentais para compreender o dinamismo de uma paisagem. Por isso, tem sido igualmente importante associar a perspectiva teórica do desenvolvimento de capacidades inerentes ao planejamento ambiental. Nesse sentido, a Biogeografia requer o desenvolvimento de habilidades em cartografia, em estatística espacial, em informática, em modelagem espacial, em técnicas de campo voltadas a observar, registrar, comparar, analisar, interpretar e construir as representações e explicações sobre a distribuição dos seres vivos." (FURLAN, SOUZA, LIMA \& SOUZA, 2016, p. 102).

O empreendimento será situado no município de São Gonçalo do Amarante, Estado do Rio Grande do Norte. O principal acesso as alternativas locacionais se dá pela rodovia BR-101 (área 01) e RN-160 (área 02 e 03). A seguir temos o mapa de localização da área do empreendimento partindo como ponto de referência o centro do Município de São Gonçalo do Amarante.

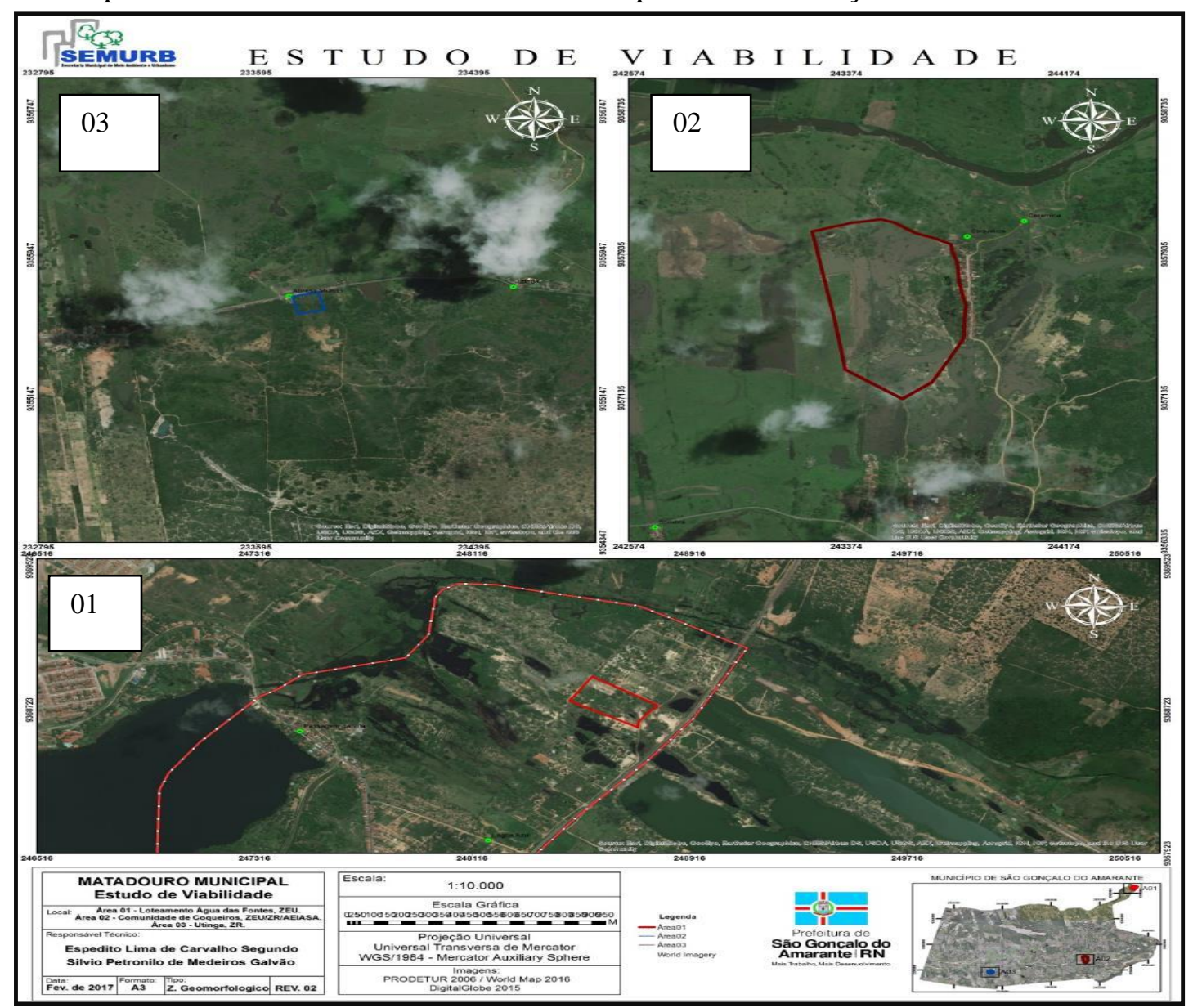

Figura 1: Mapa de Localização das Alternativas Locacionais. Fonte: SEMURB, 2017. 


\section{METODOLOGIA}

A metodologia do trabalho consistiu na revisão bibliográfica, com leitura de livros, artigos científicos e documentos oficiais do assunto abordado.

Após essa revisão, foram realizadas visitas in loco, procedimento fundamental para o reconhecimento das áreas propostas. Durante as visitas, foi possível fotografar pontos das três áreas de estudo e os arredores e foi de suma importância para identificação de solo, geomorfologia, vegetação e hidrografia.

Com essas informações organizadas, foi possível elaborar mapas referentes à localização, identificando principalmente as áreas de estudo, o zoneamento geomorfológico e ambiental. O mapeamento, bem como o layout final do mapa de localização foram elaborados por meio de um software SIG - Sistema de Informação Geográfica, no caso, a versão 10.3 do ArcGIS (ESRI C).

\section{RESULTADOS E DISCUSSÃO}

\section{ÁREA 01 - LOTEAMENTO ÁGUA DAS FONTES (BAIRRO JARDINS)}

A área 01 está localizada no Bairro Jardins, dentro do loteamento Águas das Fontes, inserida na Zona de Expansão Urbana - ZEU do município. De acordo com o banco de dados do IDEMA (2006) e observações em campo, área em questão é caracterizada geomorfologicamente como "Campo de Dunas com vegetação formando as dunas fixas" de constituição de areias quartzosas, imobilizadas sob a cobertura vegetal, elevam-se aproximadamente até 29 metros de atura, com a formação de corredores interdunares. São excelentes reservatórios de água doce, sobretudo para a recarga dos aquíferos, uma vez que as águas pluviais que penetram no solo acumulam-se facilmente. Porosidade e permeabilidade altas permitem os usos dessas áreas como reservatórios naturais de recursos hídricos para a manutenção do meio natural e demais necessidades da população; entretanto, esse tipo de solo torna-as extremamente frágeis em áreas de adensamento urbano (NUNES, 2009).

Durante vistoria realizada in loco no dia 25 de janeiro de 2017 foi observado a presença de lagoas e corredores interdunares com a vegetação primitiva de restinga (nativa) em bom estado de conservação. 


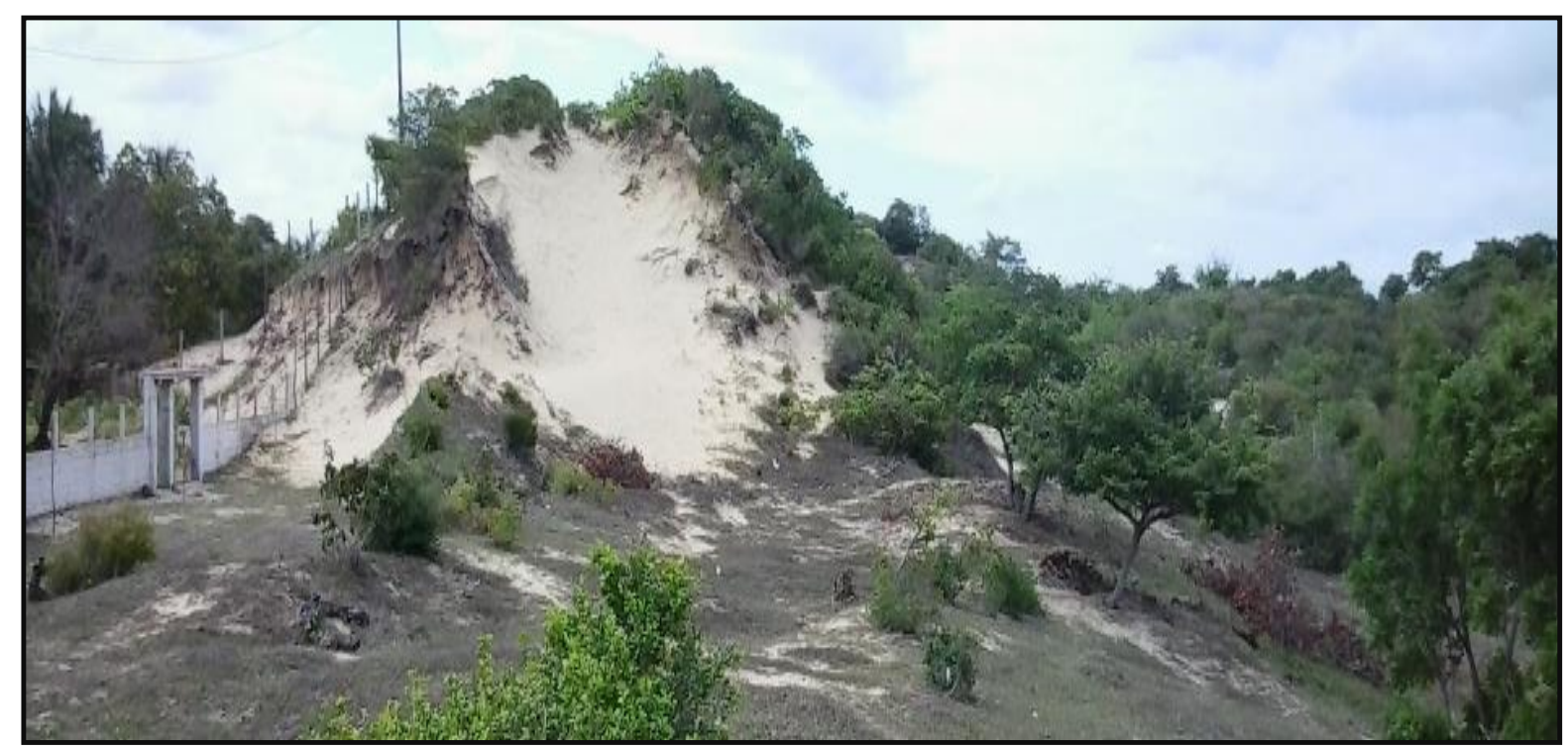

Figura 2: Dunas localizada dentro da área proposta para implantação do empreendimento. Fonte: SEMURB, 2017.

Em relação a implantação de um matadouro na área em questão, definimos que para tal tipo de atividade, o local se classifica como inadequada por possuir predominantemente coberturas de alteração arenosas e com o lençol freático mais superficial, ocorrendo periodicamente a formação de lagoas temporárias, sendo imprópria para deposição de rejeitos sólidos e efluentes líquidos, principais aspectos ambientais oriundos da atividade, acarretando em impactos ambientais de natureza negativa. As dunas são consideradas Áreas de Preservação Permanente - APP, protegidas nos termos dos arts. $2^{\circ}$ e $3^{\circ}$ do Código Florestal brasileiro e definidas segundo a Resolução n $^{\circ} 303$ do Conselho Nacional do Meio Ambiente - CONAMA, cobertas ou não por vegetação nativa, com função ambiental de preservar os recursos hídricos, a paisagem, a estabilidade geológica, a biodiversidade, o fluxo gênico de fauna e flora, proteger o solo e assegurar o bem-estar das populações humanas. Nessas áreas, não se pode fazer a retirada da cobertura vegetal original, permitindo, assim, que ela possa exercer, em plenitude, suas funções ambientais.

Utilizando-se de valores de cotas numéricas das curvas de nível obtidos por levantamento topográfico do Governo do estado do Rio Grande do Norte elaboradas no ano de 2006 (Projeto Polo Costa das Dunas), foi criado um modelo digital do terreno (figura 02) como subsídio à identificação das dunas que se encontram na altitude de 10 até 29 metros do nível do mar. 


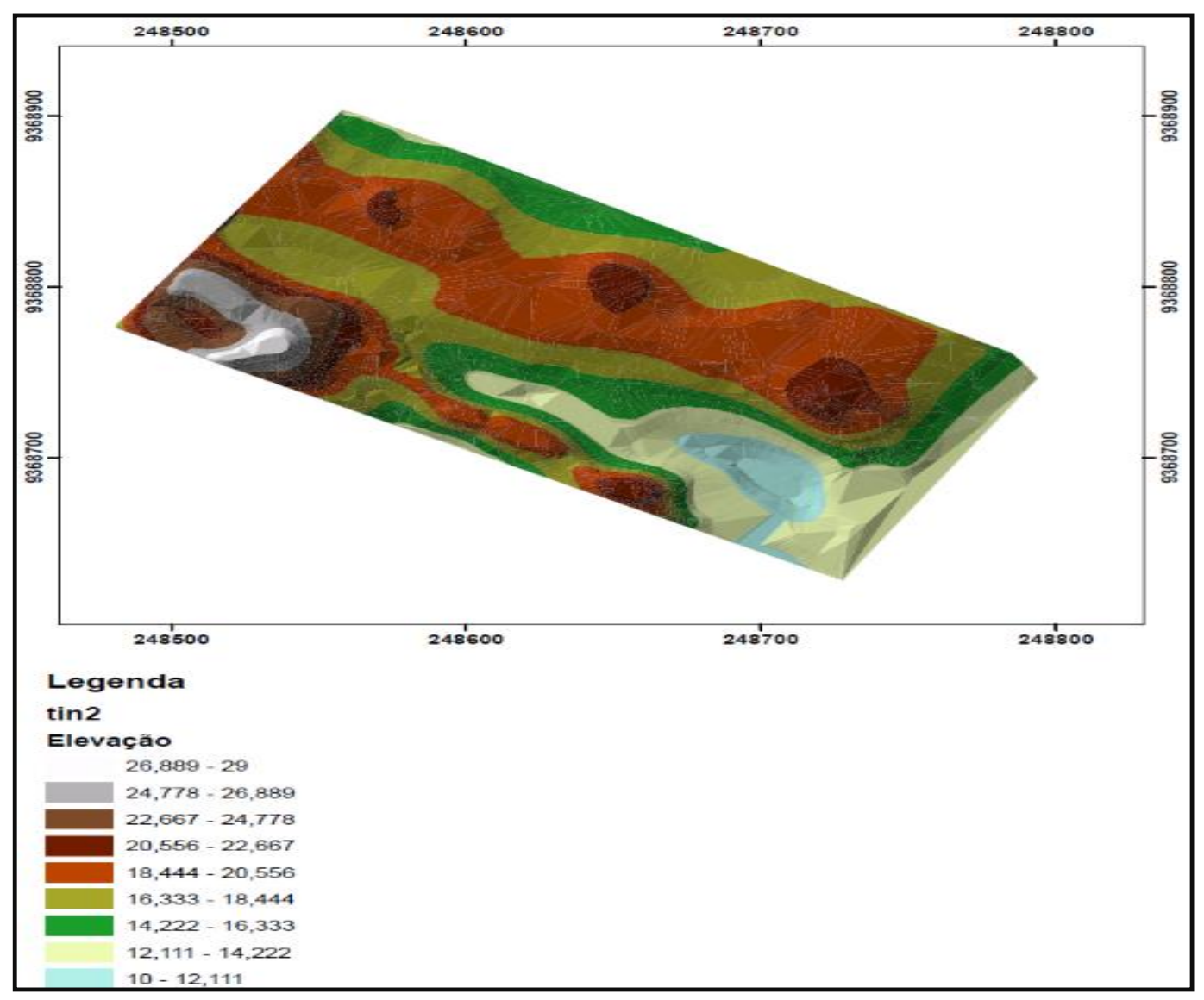

Figura 2: Modelo Digital do Terreno, Área 01. Fonte: SEMURB, 2017.

\section{ÁREA 02 - COMUNIDADE DE COQUEIROS}

A área 02 está localizada a Oeste da Comunidade de Coqueiros a qual é confrontante com o limite do terreno aonde pretende-se instalar o Matadouro. O imóvel está localizado entre as Zonas de Expansão Urbana, Rural e Área Especial de Interesse Agrofamiliar e Segurança Alimentar de acordo com a lei Complementar no 049/2009 qual institui o Plano Diretor do município.

Em um breve histórico é possível observar que a Área 02 sofreu durante vários anos a extração irregular de areia, deixando assim o imóvel com um passivo ambiental sobre tal atividade, situação essa que acabou rebaixando o relevo de parte do terreno ficando mais próximo o lençol freático da superfície, o qual aflora e alaga em alguns locais.

Através de vistoria técnica e interpretação em tela das imagens de satélites foi possível constatar vários pontos alagados devido a extração irregular de área. Foi utilizado também o Sistema de Informação Geográfica - SIG do Instituto de Desenvolvimento Econômico e Meio Ambiente - IDEMA (banco de dados de 2006), onde foi inserido a base de dados referente a Geomorfologia da área sendo classificada como área Planície de Inundação fluvial, situação essa 
que inviabiliza a implantação do empreendimento na poligonal desejada, quanto a sua futura operação e aspectos ambientais, o que comprometeria a execução da drenagem, esgotamento sanitário, resíduos sólidos, implantação de acessos etc.

Quanto a Infraestrutura local, o acesso é realizado através de estrada de barro, conta ainda com abastecimento de água, iluminação pública, telefonia móvel e fixa, coleta de lixo. A poligonal da área está localizada a aproximadamente $2.6 \mathrm{~km}$ em linha reta do centro de São Gonçalo do Amarante.

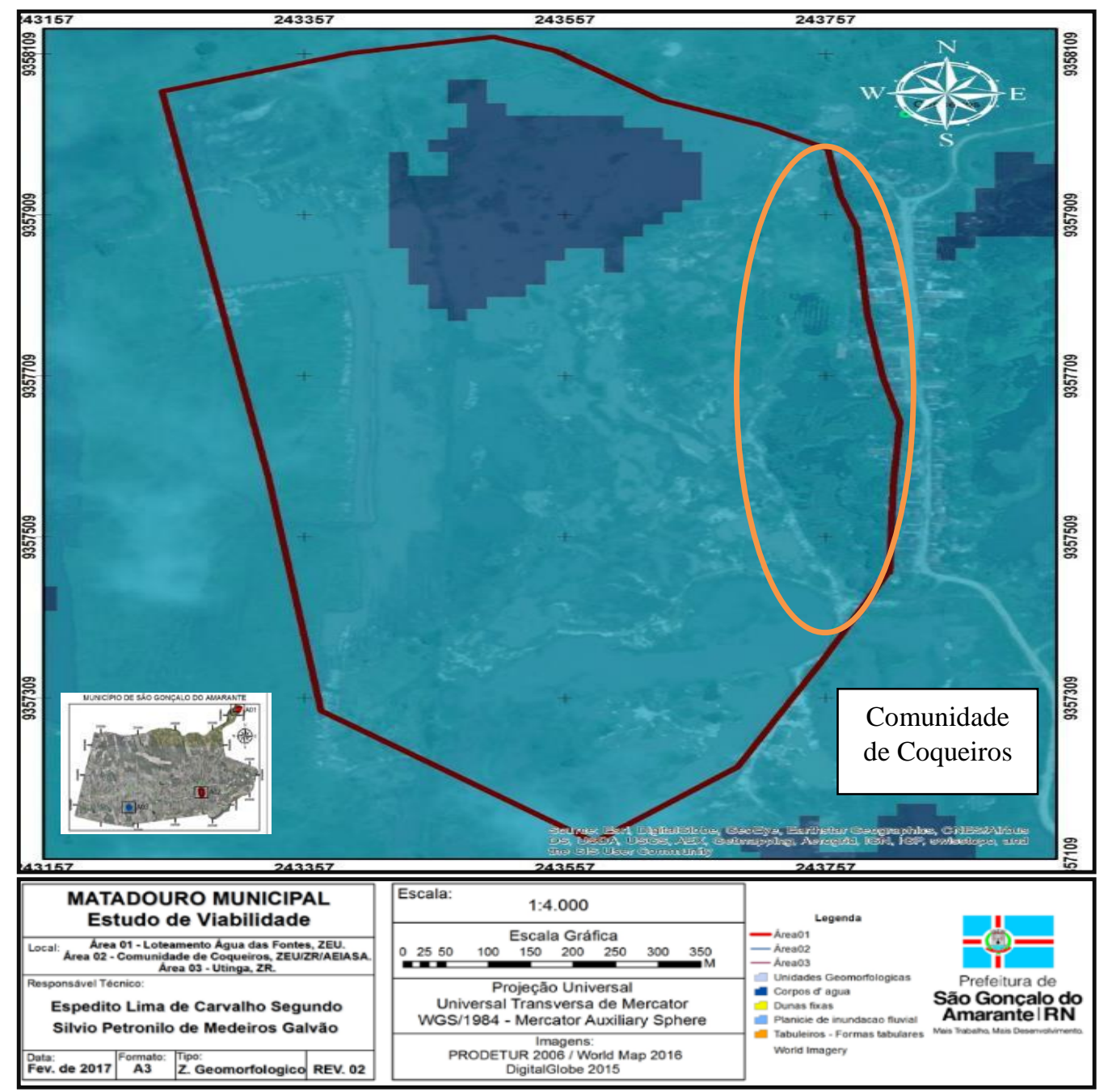

Figura 3: Mapa Geomorfológico da Área 02. Fonte: SEMURB, 2017.

\section{ÁREA 03 - COMUNIDADE DE UTINGA}

A área 03 está localizada a aproximadamente $700 \mathrm{~m}$ da Comunidade de Utinga e $13 \mathrm{~km}$ do Centro de São Gonçalo do Amarante, sendo confrontante a Norte um acampamento do Movimento dos Trabalhadores Rurais Sem Terra - MST. Em vistoria realizada na área e através da obtenção de 
dados de satélites foi possível observar e constatar que o terreno proposto é bastante plano, com uma inclinação média de 0,3\%, onde a sua altura a nível do mar varia entre 36m a 35,40m.

A vegetação da área encontra-se bastante antropizada devido a extração ilegal de madeira, produção de carvão e cultivo de monoculturas. O bioma local apresenta espécies de mata atlântica e caatinga (área transicional) sendo a espécie de maior predominância a jurema preta, Catanduva e embaúba, o qual são indicadores de vegetação secundaria o que traduz que a área foi recentemente perturbada.
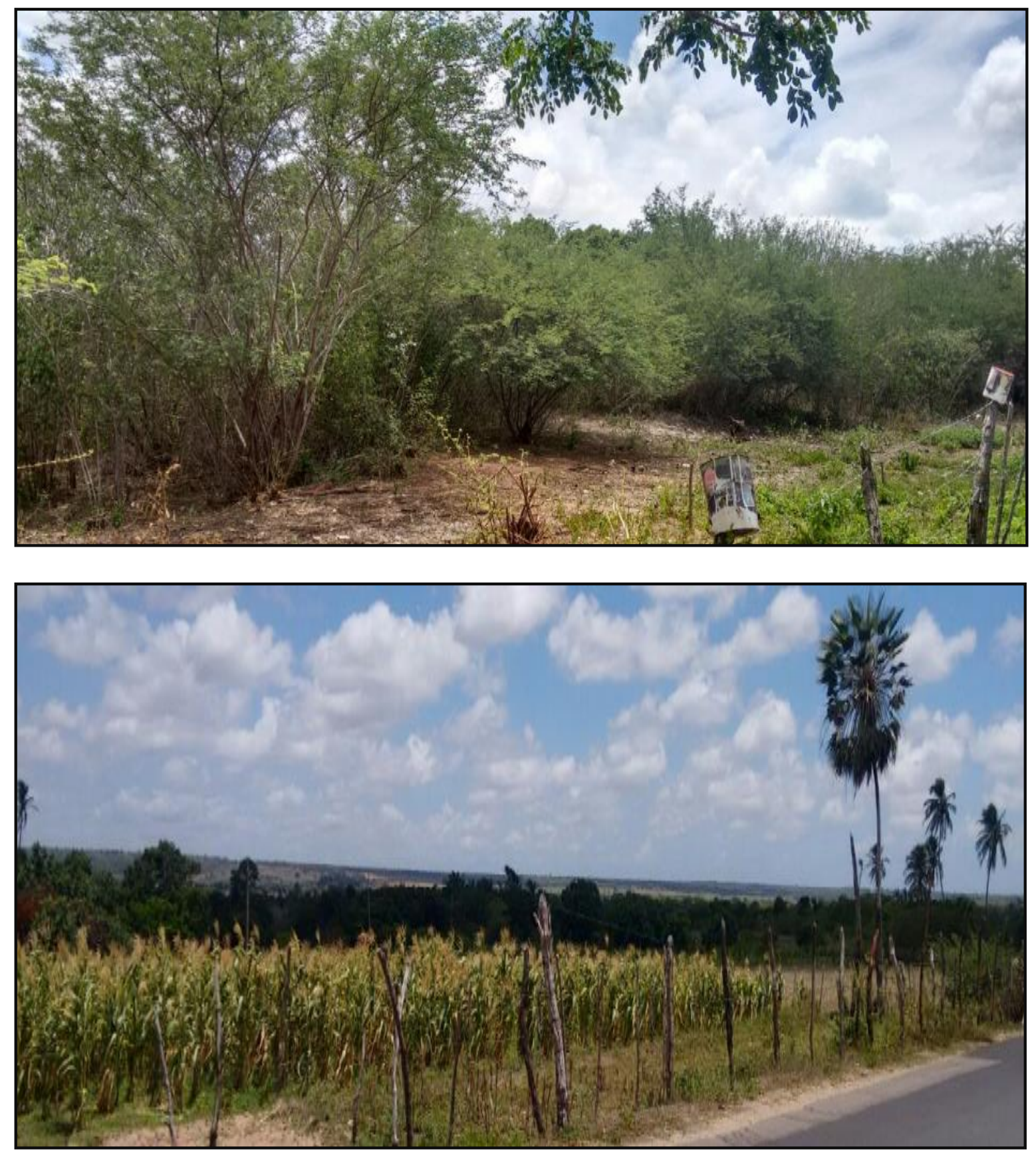

Figura 4: Vegetação Localizada na Área 03. Fonte: SEMURB, 2017. 
A Geomorfologia local é constituída por formas tabulares com vegetação cobrindo os tabuleiros, e algumas ocupações com características rurais as quais desenvolvem o plantio de milho, caju, mandioca, manga e outras espécies frutíferas.

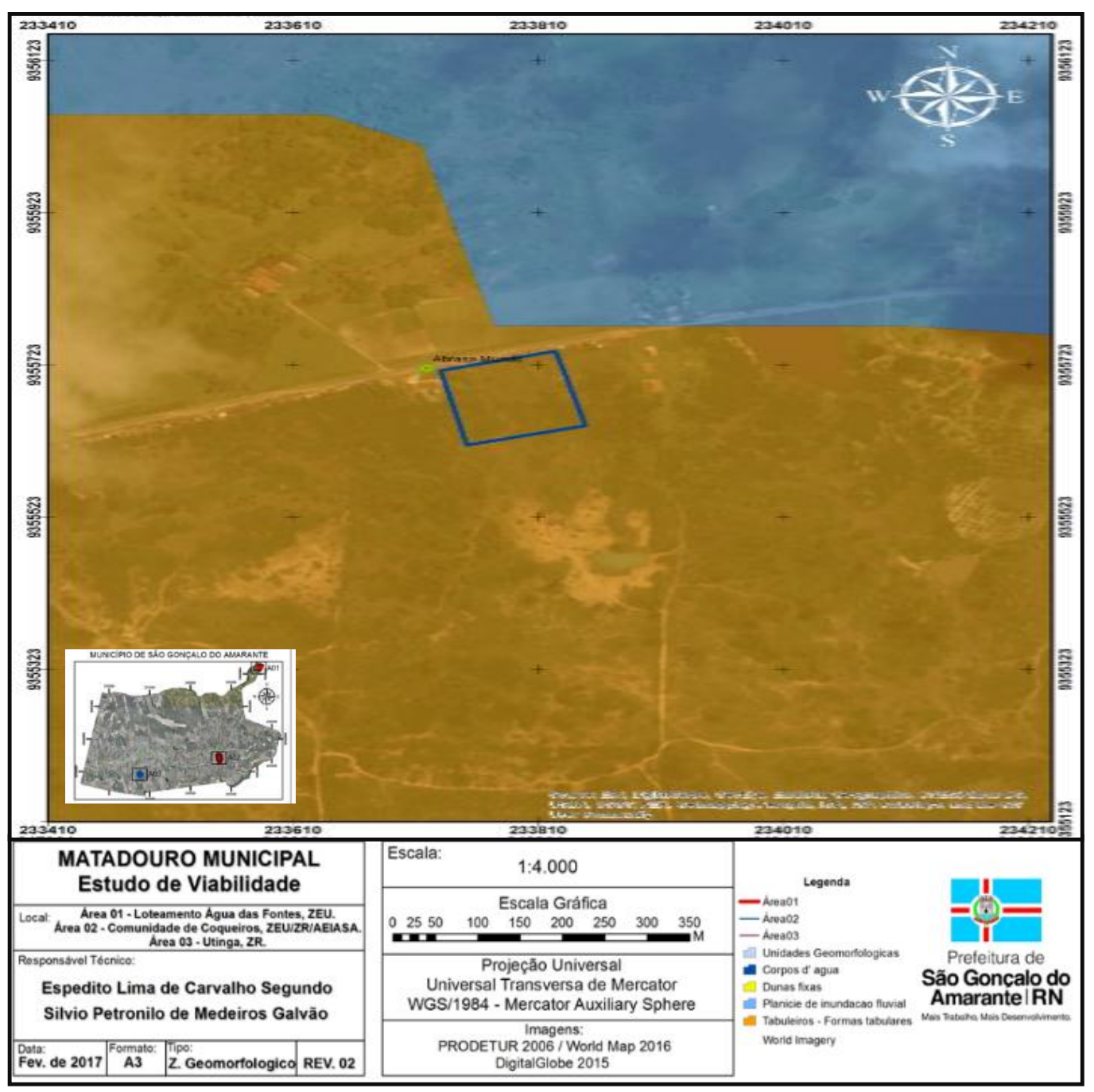

Figura 5: Mapa Geomorfológico da Área 03. Fonte: SEMURB, 2017.

Referente a hidrografia da área, a gleba não possui recursos hídricos superficiais, nem áreas ambientalmente sensíveis, o recurso hídrico mais próximo está localizado a 700m de distância, onde faz parte da bacia hidrográfica do Rio Potengi. A área e bastante favorável para implantação do empreendimento não possuindo assim nenhuma restrição do ponto de vista ambiental. 


\section{CONSIDERAÇÕES FINAIS}

Através das observações in loco e fotointerpretação do mapeamento elaborado da integração das características ambientais das áreas de interesse estudadas (relevo, vegetação, solos e hidrografia), permitiram a realização de uma análise que teve por finalidade indicar a área ambientalmente viável e com uso adequado para a atividade.

Por fim, no que concerne às alternativas locacionais sugeridas para futura implantação do empreendimento, temos a Área 03 localizada em na comunidade de Utinga - São Gonçalo do Amarante/RN como sendo a mais favorável e adequada para tal finalidade, tanto do ponto de vista geoambiental, pois a área possui características físicas e bióticas, como uma área de relevo plano e propício e vegetação já bastante atropizada, com espécies predominante de jurema preta, Catanduva e Embaúba, o qual são indicadores de vegetação secundaria o que traduz que a área foi recentemente perturbada. Dessa forma, podemos concluir que esta área foi a mais viável do ponto de vista ambiental, que comporta a atividade e quanto à legislação ambiental vigente.

\section{REFERÊNCIAS}

ARAÚJO, P. P. P.; COSTA, L. P. Impactos Ambientais nas Atividades de Abate de Bovinos: um Estudo no Matadouro Público Municipal de Caicó-RN. Revista Holos, 2014.

BRASIL. Conselho Nacional do Meio Ambiente. Resolução 303, de 20 de março de 2002. Dispõe sobre os parâmetros, definições e limites de Áreas de Preservação Permanente de reservatórios artificiais e o regime de uso do entorno. Diário Oficial da União, Brasília, 13 mai. 2002.

BRASIL. Lei $n^{\circ} 12.651$, de 25 de maio de 2012. Dispõe sobre a proteção da vegetação nativa; altera as Leis nos 6.938, de 31 de agosto de 1981, 9.393, de 19 de dezembro de 1996, e 11.428, de 22 de dezembro de 2006; revoga as Leis nos 4.771, de 15 de setembro de 1965, e 7.754, de 14 de abril de 1989, e a Medida Provisória no 2.166-67, de 24 de agosto de 2001; e dá outras providências.

Lei Complementar $n^{\circ} 049$ de 2009: institui o Plano de Diretor do Município de São Gonçalo do Amarante/RN.

NUNES, Elias. O Meio Ambiente da Grande Natal. 2 ed. rev. atual. e ampl. Natal: Elias Nunes, 2009, 188 p.

FRANCO, E. Biogeografia do Estado de Sergipe. Imprensa: Aracaju/SE, Segrase, 1983. 139 p. 
GOMES, L. J.; SANTANA, V.; RIBEIRO, G. T.Unidades de Conservação no Estado de Sergipe. Revista da Fapese, v. 2, n. 1, p. 101-112, jan./jun. 2006. Disponível em: <http://www.fapese.org.br> Acesso em 20/09/2007.

FURLAN, Sueli Angelo; SOUZA, Rosemeri Melo e; LIMA, Eduardo Rodrigues Vians de; SOUZA, Bartolomeu Israel de;. Biogeografia: reflexões sobre temas e conceitos. Revista da Associação Nacional de Pós-graduação e Pesquisa em Geografia (Anpege).p.97-115, V.12, n.18, especial GT Anpege 2016.

MALDANER, T. L. Levantamento das alternativas de minimização dos impactos gerados pelos efluentes de abatedouros e frigoríficos. Brasília: UCB, 2008. Disponível em: <http://www.qualittas.com.br/principal/uploads/documentos/Levantamento\%20das\%20Alternativas \%20de\%20Minimizacao\%20dos\%20Impactos\%20-\%20Tania\%20Luisa\%20Maldaner.PDF>.

Acesso em: 02 ago. 2017.

PACHECO, J. W; YAMANAKA, H. T. Guia técnico ambiental de abate. São Paulo : CETESB, $2006 . \quad$ Disponível em: http://www.cetesb.sp.gov.br/tecnologia/producao_limpa/documentos/abate.pdf. Acesso em: 5 ago 2017.

SANTOS, C. de Resende; CARVALHO, Márcia Eliane Silva. A Contribuição da Biogeografia na Formação do Geógrafo: Os Desafios de Ensinar e Aprender Geografia Física e Educação Ambiental. REVISTA GEONORTE, Edição Especial, V.3, N.4, p. 1-11, 2012.

\section{AGRADECIMENTOS}

A elaboração deste trabalho não teria sido possível sem a colaboração, estímulo e empenho de diversas pessoas.

Ao Secretário de Meio Ambiente e Urbanismo do município de São Gonçalo do Amarante, Paulo de Tarso Dantas Lima e também a equipe do setor de Meio Ambiente.

Agradecemos também, ao Doutor Diógenes Félix da Silva Costa, professor do Departamento de Geografia da Universidade Federal do Rio Grande do Norte - Campus de Caicó, pelas orientações para esta pesquisa.

Recebido em: 15/08/2018

Aceite para publicação em: 05/11/2018 